Journal of English Language Teaching

\title{
Strategies employed by EFL teachers at a Vocational High School for selecting appropriate English textbook
}

\author{
Siti Maftukah ${ }^{\bowtie 1}$, Puji Astuti $^{2}$
}

${ }^{1,2}$ English Department, Faculty of Language and Arts, Universitas Negeri Semarang, Indonesia

\begin{tabular}{l} 
Article Info \\
\hline Article History: \\
Received in 28 May \\
2020 \\
Approved in 8 \\
November 2020 \\
Published in 30 March \\
2020 \\
\hline Keywords: Teachers' \\
strategies; appropriate; \\
English textbook selection
\end{tabular}

\begin{abstract}
Textbook is a tool which functions as a manual instruction in any branch of study included in language learning. Therefore, teachers should select an appropriate English textbook to support the learning activity because it have a big influence in the learning process. This study is about strategies of EFL teachers at a vocational high school in Semarang for selecting appropriate English textbook. The main purpose of this study was to investigate teachers' strategies in selecting appropriate English textbook and dr. This study drew from the teachers regarding their criteria in selecting appropriate English textbook. Hence, this is a qualitative study that investigate the EFL teachers as the subjects. In collecting the data, we used open ended interview, questionnaire, and document analysis checklist. This study eployed theory of Garinger (2002) and BNSP by Permendikbud (2013) to analyse the data in order to know the strategies and the criteria used by the teachers in selecting appropriate English textbook. Based on the interview and the questionnaire, the finding showed there are some strategies in selecting appropriate textbook: teacher matched the textbook with the 2013 curriculum, read the KI, KD, Syllabus and learning objective. The data showed that all teachers select textbook based on their chosen, so that they were free to choose their textbook to support learning activity. However, some teachers select textbook by involving administrator and head school. There are also some textbook criteria there are: considering the goals and curriculum, textbook series, learning objective in the textbook, the age and background of the students, the availability and the effective cost. Based on the document analysis checklist, this research showed that the criteria of appropriate textbook in line with the Garinger (2002) and 2013 curriculum aspects based on BNSP. Next, the teachers also considered about the price of the textbook that must be cost effective and the textbook is easy to obtain. We argue that the identified strategies and criteria can be used as a consideration by English teachers to selectan appropriate English textbook.
\end{abstract}

(C) 2021 Universitas Negeri Semarang

${ }^{\square}$ Correspondent Address:

B3 Building FBS Unnes

p-ISSN 2252-6706 | e-ISSN 2721-4532

Sekaran, Gunungpati, Semarang, 50229

E-mail: sitimaftukah1@gmail.com 


\section{INTRODUCTION}

In this modern era, there are many modern media that are used to support teacher and students in teaching learning process, such as video, e-book, power point, LCD projector and etc. However, the most common teaching and learning material which guide teachers and learners in many classrooms are textbooks. Textbook is a tool which functions as a manual instruction in any branch of study included in language learning. Research by Rindawati (2013) showed that English Language Teaching (ELT) textbook plays a very important role in language classrooms. It has been more crucial when English is learnt as foreign language like in Indonesia. Richards (2001) state that textbook is used in different ways in language programs. For example, a reading textbook might be the basis for a course on reading skills, providing both a set of reading texts and exercises for skills practice. A writing textbook might provide model compositions and list of topics for students to write about. A grammar textbook might serve as a reference book and provide example as well as exercise to develop grammatical knowledge. A speaking text might provide passage for students to read and discuss. A listening text together with audiocassettes or CDs might serve as the primary listening input in a listening course.

Textbooks can provide the materials that help the student to understand about the subject beside given explanation by the teacher. According to Richards (2001) teacher need good materials to teach from either in form of commercial textbooks or institutionally prepared materials. Nothing is more demotivating to teacher than having to use a textbook that no one likes or materials that are poorly prepared or presented. Without a textbook, the material that delivered by the teacher will be forgotten quickly. So by textbook, the student can learn by themselves and try to explore more about the material.

The textbook is one of the crucial factors in determining the learners' success in language courses. Teachers or curriculum developers should select this teaching material carefully. Selecting a good material to support the teaching and learning process has a great influence on the success of a teacher when implementing the learning process (Brown, 1994). Textbook can be the model of learning. In the textbook there are a lot of exercise and task that can improve the student ability. Considering the importance of the textbook, it is necessary for EFL teachers to select appropriate textbook carefully since textbook do not only influence what and how students learn, but also what and how teacher teach.

Textbook selection is a significant educational and administrative decision in which there is considerable financial, professional and even political investment (Sheldon, 1988). Teachers have right in selecting textbook as it use for their teaching guide and learning material. In some school the textbook selection process involve not only the teachers but also the school staff. Masuhara (1998) in Mijayanti (2015) suggests that teachers who conduct the textbooks selection have to consider the students', teachers', and administrators' needs and wants. Students' needs refer to the personal, learning, and future professional needs. Meanwhile, teachers' needs include personal and professional needs, while administrators' needs cover the socio-political needs, educational policy, and some limitations such as financial problem.

Selecting the appropriate textbook for use in the English classroom is not an easy way. Thus teachers are required to make informed and appropriate choices when selecting textbook (Rubdy, 2003). Textbook are also under the influence of constraints, such as economics, and precedents set by states (Hubisz, 2003). Teachers should have the criteria on selecting which book they are going to use. Kay (2006) stated that the criteria for selecting textbook different from one person to another based on their context.

Now days, there are varieties of textbook published in the market to provide student's requirement in learning process. This is both an advantage and disadvantage. It increases the possibility of selecting most appropriate one between many references of the textbook. On the other hand, it also increase of the selecting process to be more careful because not all textbook are appropriate. For this reason, it is a must to spend a lot of energy and time on the textbook selection process.

There is a variety of the approaches for textbook selection. One of the most practical method is considering the general goals and the curriculum of the program at first step and specific details as exercise and actives at later steps (Amerian, 2014). Garinger (2002) stated that curriculum of the program should be examined closely to see whether the goals are clearly defined. After that, it should be evident whether the objective of the textbook matches the objective of the course or not. 
Richards (2001) identified four types of factors, which are essential for textbook selection and evaluation: a) program factors b) teacher factors c) learner factors d) pedagogical factors. Another important criterion is the intended learners. The material should be interesting for them and satisfying their needs.

The states above shows that textbook is important role in learning activity in order to guide he students for mastering the material. Selecting appropriate textbook is needed for the teacher to get the good reference or guidance in their teaching activity. They need the staregies and criteria in selecting appropriate textbook to get the best textbook.

\section{Review of Previous Studies}

Many studies have proved that textbook selection is one of the crucial aspects in learning activity (e.g. Lemmer, 2008; Mijayanti, 2015; Ișık \& Kurum, 2002; Sikorova, 2004; Watt, 2009; Ho and Hsu, 2011; Yuen and Ting, 2012; Amerian and Khaivar, 2014; Marczak, 2013; Chang, 2002; Huang, 2011; Kim, 2002; Garinger, 2002; Kiai and Maroko, 2013; Frediksson \& Olsson, 2006; Mahmood, 2011; LaBelle, 2010; Deuri, 2012). For the criteria of appropriate English textbook, researchers have discovers many criteria used by the teacher in selecting their textbook (e.g. Rahimpour, \& Hashemi, 2011; Makgato \& Ramaligela, 2013; Rodriguez, 2015; Reid, 2017; Mukundan, 2011; Akbar, 2016; Shabani, 2017).

Most of the previous studies focused on textbook selection evaluation. Then, they described what are the evaluation techniques in selecting textbook that used by the teacher. They did not explain what the strategies in selecting appropriate textbook are. It was very important to give detailed description about how the teachers' strategies in selecting appropriate textbook. Therefore, in this study focused on the description of what and how strategies of the teachers' in selecting appropriate textbook for their learning tools. From the gaps found that the study has different field of subjects. Most of the previous studies conducted their study without focusing on certain school. This was important to to conduct the study focusing on the certain school to give limitation of the study.

Based on these gaps, the study focused on how EFL teachers' strategies in selecting appropriate textbook. The strategies here is included the procedure and the criteria of an appropriate textbook. One of main reason for conducting this study because there were just few studies discuss in detile how the strategies and criteria were used by theacher since selecting appropriate textbook was important to support teaching and learning process.

\section{METHOD}

This study was qualitative research, Creswell (2013) stated that like other forms of qualitative research, the researcher would seek to explore, and understand and present the participants' perspectives and get close to them in their natural setting. This study employed qualitative case study method to answer the research questions. It focused on teacher's strategies in selecting appropriate textbook. The area of the investigation was about the teacher's process and criteria in selecting appropriate textbook. Qualitative case study was chosen in this research because it was the most suitable method to conduct an in-depth analysis of an issue since this research investigated the teacher's strategy through questionnaire, interview and document analysis.

\section{Research Participants}

The research was conducted at a vocational high school in Semarang. In this study, we positioned teachers as the subjects; they were our research participants. The school was selected based on some consideration. The first one was because the first author did her teaching practice Praktik Pengalaman Lapangan/PPL there for 45 days so she knewthe school. The second was the teacher used varied textbooks to support their teaching activity. This was supportive of the present study. Third, the teachers at the school had a good experience and background in teaching English, hence, they could provide the needed data.

\section{Data Collection Methods}

This study used questionnaire, interviews and document analysis. The questionnaire was to find out teachers' criteria of appropriate textbook they choose. The interview was to display how does the teachers' strategies in selecting appropriate textbook, and how the process of textbook selection. In the document analysis, the textbook was analyzed based on the data result after conducted the 
questionnaire and interview. This aims to find out whether the textbook used by the teacher was accordance with the teachers' criteria or not.

\section{Data Collection Procedures}

The data collection procedures in this study was questionnaire, interview, and document analysis. The first step to do was distribute the questionnaire to the teacher participants. Specifically, in the questionnaire, we used checklist as an instrument for textbook selection. The checklist instrument was a combination of Garinger (2002) and the standards for the 2013 Curriculum. Checklist by Garinger (2002) covers the questions related to teachers' strategy and criteria in selecting appropriate textbook, then the 2013 curriculum provided textbook standard that should suit with students' learning needs.

Interview was also the next procedure of collecting the data. In the interview section, the teacher was interviewed with several questions to see how the process of textbook selection and what the criteria of appropriate textbook. While doing an interview, we recorded the conversation and take notes.

Lastly, to gain the trustworthiness, we did document analysis by taking the sample of textbook used by the teachers. The textbook used by the teachers was analyzed based on the identified criteria of good textbook. By doing the document analysis, we examined whether or not the textbook was relevant with the teachers' criteria.

\section{Data Analysis}

This study employed a qualitative technique in analyzing the data. This research used technique of data analysis based on Miles and Huberman (1994) as stated in Sugiyono (2014). The data analysis involved three steps: data reduction, data display, and conclusion drawing/verification.

However, in conducting qualitative research method, the data bias might occur and the findings were often doubtful for several reasons such as the subjectivity of the researcher, the instruments used is considered have many weaknesses, and the data sources less trustworthy that affect the results (Bungin, 2014). To avoid that assumption, this study used triangulation. Triangulation is defined as the mixing of data or methods so that diverse viewpoints or stand points cast light upon a topic (Oslen, 2004). The data sources triangulation carried out by comparing the all data already collected: questionnaire, interview, and document analysis.

\section{FINDINGS AND DISCUSSION}

Based on the questionnaire, interview, and document analysis that have been concucted, the data showed the EFL teachers' the strategies and criteria for selecting appropriate English textbook.

\section{Findings \\ Teachers' Strategies in Selecting Appropriate English Textbook}

This finding answered the research question based on the questionnaire and teacher interview. By doing questionnaire, it found how the textbook are selected. The teachers filled out the questionnaire sheet based on their own experience. Afterwards, the teacher gave explanation about their strategies in selecting appropriate textbook through interview.

\section{How Textbook Are Selected}

In the questionnaire sheet, we gave six items of questionnaire about how textbook are selected. Those items are: administration select the textbook, department head select textbook, teachers all together select textbook, teacher select textbook, learners get involved in selecting textbook, and there is a textbook criteria. Here is what we found in the teachers' answers.

The results showed that administration and department head chose the English textbook used at the school. Their contribution was approximately $50 \%$. Teachers all together as a teamand individual teachers selected the textbook; they did it regularly. It indicates that all the EFL teachers at the school selected English textbook based on his or her criteria and a team of teacher was involved in the process of selecting English textbooks. In addition, the result showed that learners were not involved in the selection process. While selecting appropriate textbook, teachers have criteria. These criteria will be explained in the next discussion. 


\section{Teachers' Strategies in Selecting Appropriate English Textbook}

At the time of this study, four teachers were interviewed several questions to find out what the strategies do they employ in selecting a textbook. In this investigation, we found the teachers' steps of selecting appropriate English textbooks.

The firs teacher is Mrs. Lusi. In selecting an appropriate English textbook, Mrs. Lusi did a meeting with MGMP team in the school. The teachers compared the book with another publisher. The price of the textbook was also one of the considerations. The teacher made use of exiting textbooks instead of buying a new one. To complete material that does not exist, the teacher completed it by making a handout. Based on the interview, Mrs. Lusi involved another participant in selecting a textbook that is the MGMP team. The selection process was by comparing the textbook with another publisher by considering the price and exiting textbooks.

The second teacher is Mrs. Lala. In selecting appropriate English textbook, Mrs. Lala adjusted with the industrial needs and the curriculum. The best textbooks were those that fit the curriculum. That was one of the consideration of Mrs. Lala in selecting appropriate textbook. Based on the interview, the step of selecting textbook were matching the textbook with the curriculum and industrial need with considering the price. Then Mrs. Lala involved the coordination of the school about the price. The process of textbook selection was without involving another participant, but if the students must purchase the textbook, it involved the school cooperation because teacher cannot sell the textbook.

The tird teacher is Mr. Koko. Mr. Koko selected the textbook by see the syllabus, KI, KD, and the learning objective. After known what the syllabus, KI, KD and the learning objective, he matched it with the textbook candidate. He used the e-book from the government but that was not the main book. In his opinion, the textbook by government did not present listening skill so he use another textbook from another publisher to cover it. According to the result of the interview, there was no interference from other parties in selecting textbook. Mr. Koko selected the textbook by himself with considering the criteria that is suitable with the syllabus, curriculum, $\mathrm{KI}, \mathrm{KD}$, and learning goals.

The fourth teacher is Mr. Sapto. Mr. Sapto used textbook from the government, which has been provided by school, but if he wanted to use another textbook for the initiative textbook, he discussed it to head school. The meeting was not a formal meeting, just the informal meeting where the teacher asked about the approval. The head school involved in approving the textbook selection because it considering the price of the textbook. According to the interview, Mr. Sapto selected the textbook by himself and if there was additional textbook as an initiative, he needs the consideration from the head school. After the textbook were approved by the head school, Mr. Sapto coordinated with the school library. Then the textbook would be distributed to the student trough the school library administrator.

According to the data from teacher interviews, teachers used the textbook from the government, but the teachers still use the textbook from another publisher to support the materials. In selecting the appropriate English textbook, the teachers have some steps. In accordance with the interview, teachers selected the textbook by matching the textbook with the KI, KD, current curriculum and industrial needs. After that, the teacher did an informal meeting with another teacher to make coordination about the textbook. Even there was a meeting with another English teacher in the school; still the teacher itself has his or her own choice. Then teachers did a comparison with other English textbooks to see which one is the appropriate accordance with their criteria of textbook. One of the considerations was about the price of the textbook. Most of the textbooks were free for students; the students could borrow the textbook in the library.

\section{Teachers' Criteria of Appropriate Textbook}

Based on the data found after conducting the questionnaire and interview, all teachers used the criteria of appropriate textbook. The teachers' criteria are: textbook must support the goals and curriculum program, it is better that the textbook is part of the series, the textbook must address the learning objective, and then the textbook must base on the learner's age and backround. The teacher also see the content criteria that was created by the BNSP such as: the suitability with the core competent (KI) and basic competent (KD), the material accuracy and the material supplementary. For the practical concern criteria was also be consicedered by the teacher such as: the availability of the textbook, the textbook can be obtained in timely manner, and cost-effective. 


\section{Discussion}

This present study answered the research question. It was to find out the EFL teachers' strategies in selecting an appropriate English textbook at the vocational high school. Moreover, this study drew the criteria of EFL teachers in selecting an appropriate English textbook. This section discusses the study's findings resulted from our analysis of questionnaire, interview, and document analysis data. We discuss the findings withwith our theoretical framework in mind and in connection with the findings of the existing studies.

Textboojk was one of the most important tools to support learning activities. According to the questionnaire and interview, teachers have the steps and criteria in selecting an appropriate English textbook. Ensuring the criteria of appropriate textbook helps teachers deciding which textbook that they will use.

In accordance with the questionnaire and interview, Mrs. Lusi selected textbook by involving consideration of administration school, department head, all teachers, and the teacher itself. She did not involve the students in selecting process. This result finding was in line with Isik and Kurum (2002) that the teacher did not select the textbook by themselves.

Mrs. Lusi also had criteria in selecting an English textbook. In the questionnaire checklist about the criteria of appropriate textbook was in line with the criteria of appropriate textbooks by Garinger (2002) that she selected textbook by considering the goals and curriculum, textbook series, course objective in the textbook, the age and background of the students, the availability and the effective cost. It was also in line with the 2013 curriculum aspects that the textbook must be suitable with KI and $\mathrm{KD}$, the material should be accurate provided social function, linguistic features, and the generic structure. Mrs. Lusi also considered the supplementary material that the material and the exercise in the textbook should be up to date, developed the life skill, and wawasan kebhinekaan.

Next teacher was Mrs. Lala. Based on the interview with Mrs. Lala, she selected appropriate textbook by involving many participants, those were administration, department head all EFL teachers and learners. There were also criteria of appropriate textbook. This result finding also strengthens the research by Isik and Kurum (2002). In selecting appropriate textbooks, Mrs. Lala adjusted to the industrial needs and the curriculum. Then there was an offering from the publisher so that Mrs. Lala will choose the textbook that she were going to use. In this result finding were accordance with research by Kiai and Maroko (2013) that the procedure of selecting a textbook based on the marketing by the publisher.

In the criteria of appropriate textbook, Mrs. Lala's criteria were accordance with Garinger (2002) that she selected textbook by considering the goals and curriculum, textbook series, course objective in the textbook, the age and background of the students, the availability and the effective cost. It was also in line with the 2013 curriculum aspects based on BNSP that the textbook must be suitable with $\mathrm{KI}$ and $\mathrm{KD}$; the material should be accurate provided social function, linguistic features, and the generic structure. Mrs. Lala also considered the supplementary material that the material and the exercise in the textbook should be up to date, develop the life skill, and wawasan kebhinekaan.

Mr. Koko selected English textbook see the syllabus, KI, KD, and the learning objective. After known what the syllabus, KI, KD and the learning objective, he matched it with the textbook candidate. Based on the questionnaire, he selected textbook without involving the school administration, department head school, and the learners. He selected textbook by himself and other English teachers. This result finding does not in line with Isik and Kurum (2002). Based on the interview and the questionnaire was line with Garinger (2002) that he selected textbook by considering the goals and curriculum, textbook series, learning objective in the textbook, the age and background of the students, the availability and the effective cost. He also in line with the 2013 curriculum aspects based on BNSP that the textbook must be suitable with $\mathrm{KI}$ and $\mathrm{KD}$; the material should be accuracy provided social function, linguistic features, and the generic structure. He also considered about the supplementary material that the material and the exercise in the textbook should be up to date, develop the life skill, and wawasan kebhinekaan.

According to data interview from Mr. Sapto, it relevant with the research finding by Isik and Kurum (2002) that was for the initiative textbook, if it required students to buy, the selection involved the head department. The involvement of the head school here means he just conducted the informal meeting consulting about the textbook that he would going to use. However, for the main textbook Mr. Sapto used the book by the government.

Based on the questionnaire and interview, Mr. Sapto selected textbook by considering the goals and curriculum, textbook series, course objective in the textbook, the age and background of the 
students, the availability and the effective cost. This result was in line with textbook criteria by Garinger (2002). It was also in line with the 2013 curriculum aspects based on BNSP that the textbook must be suitable with $\mathrm{KI}$ and $\mathrm{KD}$; the material should be accuracy provided social function, linguistic features, and the generic structure. Mr. Sapto also considered about the supplementary material that the material and the exercise in the textbook should be up to date, develop the life skill, and wawasan kebhinekaan.

Next, we compared the result of this study with the previous studies. The result of this study was almost the same with the result of some previous studies. The different was most of the previous studies are focused on the criteria of the appropriate textbook. They did not explaining how teacher select their textbook. Whereas this study focused on the strategies including how textbook are selected, how the step of selecting appropriate English textbook and the criteria of appropriate textbook. In this study, we aimed to give the readers detail information about the teachers' step and their criteria for selecting appropriate textbook for their English instruction.

\section{CONCLUSION}

Based on the study that has been done, we drew the following conclusions. There are some strategies in selecting appropriate textbook. First, teacher matched the textbook with the recent curriculum, which is 2013. Then the teacher read the KI, KD, Syllabus and learning objective. Based on the questionnaire, all teacher select textbook based on their chosen, so that they were free to choose their textbook to support learning activity. Beside the teacher select textbook based on their chosen, there is still the teachers who select textbook by involving administrator and head school.

The textbook criteria are important to get an appropriate textbook. After conducting the research, there are some criteria of appropriate textbook that the teacher use. The criteria is in line with Garinger (2002) and BNSP 2013 curriculum. The criteria that the teacher use in selecting appropriate textbook are by considering the goals and curriculum, textbook series, learning objective in the textbook, the age and background of the students, the availability and the effective cost. This research showed that the criteria of appropriate textbook in line with the 2013 curriculum aspects based on BNSP that the textbook must be suitable with $\mathrm{KI}$ and $\mathrm{KD}$, the material should be accuracy provided social function, linguistic features, and the generic structure. Next, the teachers also considered about the supplementary material that the material and the exercise in the textbook should be up to date, develop the life skill, and wawasan kebhinekaan.

The three teachers at the school used a textbook provided by the government as the main textbook. The other one used a textbook from a local publisher after taking into consideration some aspects. In this case, we conducted the analysis on the textbook mostly used by the teachers. The document analysis showed that the book used by the teachers is accordance with the criteria of appropriate English textbook.

For future studies, we suggest reserachers to investigate the role of the textbook in the classroom activities. By conducting this line of inquiry, we will know whether or not teachers use the selected book appropriately. A good textbook will not be beneficial for learners if it is not used properly.

\section{REFERENCES}

Akbar, Rizky. (2016). An analysis of selected eleventh grsde English textbooks. Journal of English and Education, 4(1), 109-126. Retrieved from https://media.neliti.com/media/publications/192500-EN-none.pdf

Amerian, Majid, \& Khaivar, Alimorad. (2014). Textbook selection, evaluation and adaptation procedures. International Journal of Language Learning and Applied Linguistics World (IJLLALW), 6 (1), 2289-3245. Retrieved from https://www.researchgate.net/publication/320172366_Textbook_Selection_Evaluation_and _Adaptation_Procedures

Brown. (1994). Selecting Instructional Materials: A Guide for K-12 Science. Washington, DC: The National Academies Press. https://doi.org/10.17226/9607

Bungin, Burhan. (2014). Metodologi penelitian kualitatif. Jakarta: Kencana

Chang, Yu Fang. (2002). A study on English texrbook selection for elementary school. ChungHsing: National ChungHsing University.

Creswell, J. W. (2013). Qualitative inquiry and research design: Choosing among five approaches (3rded.). Thousand Oaks, CA: Sage. 
Deuri, Champak. (2012). An evaluative study of text book in English at higher secondary level. International Journal of Science, Environment and Technology, 1(1). Retrieved from http://www.ijset.net/journal/15.pdf

Frediksson, Cecilia, \& Olsson, Rebecca. (2006). English textbook evaluation. An investigation into criteria for selecting English textbooks. Student essay 15hp. Retrieved from http://hdl.handle.net/2043/2842

Garinger, Dawn. (2002). Textbook selection for the ESL classroom. Eric Digest. Retrieved from http://www.mcael.org/uploads/File/provider_library/Textbook_Eval_CAL.pdf

Ho, Hsuan-fu, \& Hsu, Ying-tsun. (2011). Improving the textbook adoption process in Taiwan. International Education Studies, 4. (4), 356-357. Retrieved from www.ccsnet.org/ies

Huang, Shu-er. (2011). Ideal and reality of textbook selection: an interview- and questionnaire- based investigation in the Taiwanese tertiary context. University of Warwick. Retrieved from http://wrap.warwick.ac.uk/36807/

Hubisz, J. (2003). Middle-school texts don't make the grade. Physics Today, 56(5), 50-54.

Işık, Ali, \& Kurum, Eyüp. (2020). How are elt materials selected in Istanbul. Iternational 1st Teaching and Learning Symposium, 1(1), 20-23.

Kay, R. (2006). Evaluating strategies used to incorporate technology into pre-service education: A review of literature. Journal of Research on Technology in Education, 38(4), 383-398.

Kiai, Wanjira, A., \& Maroko, Geoffery. (2013). Textbook selection experiences among secondary school teachers of English in Kenya. Journal of Education and Research, 1(12). Retrieved from https://www.ijern.com/journal/December-2013/12.pdf

Kim, Hae-Dong. (2002). Procedures for the selection of a textbook: a university general English course. English Teaching, 57(1).

LaBelle, Jeffrey. (2010). Selecting ELL textbooks: a content analysis of L2 learning strategies. Journal of Language Teaching and Research. 1(4), 358-369. doi: https://www.academia.edu/6865104/Marquette_University_Selecting_ELL_Textbooks_A_ Content_Analysis_of_L2_Learning_Strategies_Selecting_ELL_Textbooks_A_Content_Analy sis_of_L2_Learning_Strategies

Lemmer, Miriam. (2008). Educators' selection and evaluation of natural sciences textbooks. South African Journal of Education, 28, 175-187.

Mahmood, Khalid. (2011). Conformity to quality characteristics of textbooks: the illusion of textbook evaluation in Pakistan. Journal of Research and Reflection in Education, 5(2), 170 -190. Retrieved from http://www.ue.edu.pk/jrre

Makgato, Moses, \& Ramaligela, Sylvia Manto. (2013). Teachers' criteria for selecting textbooks for the technology subject. African Journal of Research in Mathematics, Science and Technology Education, 16(1), 32-34. doi: 10.1080/10288457.2012.10740727

Marczak, Mariusz. (2013). Selecting an e-(text) book: Evaluation criteria. Teaching English with Technology, 13(1), 29-41. Retrieved from http://www.tewtjournal.org

Mijayanti, Yuki. (2015). SMA English teachers' lived experience in selecting textbooks. Yogyakarta: Sanata Dharma University.

Mukundan, Jayakarta. (2011). Developing an English language textbook evaluation checklist: A focus group study. International Journal of Humanities and Social Science, 1(12), 105-107. Refrrited from http://www.ijhssnet.com/journals/Vol_1_No_12_September_2011/14.pdf

Oslen, Wendy. 2004. Triangulation is social Research: qualitative and quantitative methods can really be mixed. Ormskeirk: Causway Press.

Rahimpour, Massoud, \& Hashemi, Raheleh. (2011). Textbook selection and evaluation in efl context. World Journal of Education, 1(2), 84-86. Retrieved from www.sciedu.ca/wje

Reid, Eva. (2017). How to choose the right English language textbook. Problemy Wczesnej Edukacii/issues in Early Education, 1 (36), 1734-1582. Retrieved from http://cejsh.icm.edu.pl/cejsh/element/bwmeta1.element.desklight-4ed97e50-31f9-4ec5b883-ae847456d112/c/Eva_Reid_Elena_Kova_ikova.pdf

Richards, Jack, C. (2001). Curriculum development in language teaching. United Kingdom: The Press Syndicate of the University of Cambridge. Retrieved from https://victoranglo.files.wordpress.com/2012/10/curriculum-development-in-languageteaching.pdf

Rindawati, Ikhsanudin, W. (2013). An alanysis on English textbook "bahasa ingris: when english rings the bell". Tanjungpura: Education Faculty of Tanjungpura University. 
Rodriguez, Vanesa. C. (2015). Selecting a science textbook for the CLIL classroom: a checklist proposal. Oviedo: Universidad de Oviedo.

Rubdy, R. (2003). Developing materials for language teaching, Cromwell Press, 2(5), 37-57.

Shabani, Karim. (2017). Evaluation of Iranian second-grade high school English textbook. Bulletin de la Société Royale de Liège, 86(2017). 111-126.

Sheldon, E Leslie. (1988). Evaluating ELT textbooks and materials. ELT Journal, 42(4). 237-246. doi $10.1093 /$ elt/42.4.237

Sikorova, Zuzana. (2004). The textbook selection in primary and secondary school. Oostrava: University of Oostrava.

Sugiyono. (2014). Metode Penelitian Pendidikan Pendekatan Kuantitatif, Kualitatif, dan R\&D. Bandung: Alfabeta

Watt, Michael G. (2009). Research on the textbook selection process in the United States of America. IARTEM e-Journal, 2:1. Retrieved from https://files.eric.ed.gov/fulltext/ED506523.pdf

Yuen, K.K. F., \& Ting, T. O. (2012). Textbook selection using fuzzy promethee ii method. International Journal of Future Computer and Communication, 1(1). 23-25. Retrieved from http://www.ijfcc.org/papers/20-E10008.pdf 


\section{APPENDICES}

Appendix 1. Result about How the Textbook are Selected

\begin{tabular}{|l|l|l|l|l|l|}
\hline \multicolumn{1}{|c|}{$\begin{array}{c}\text { How are textbook } \\
\text { selected? }\end{array}$} & Mrs. Lusi & Mrs. Lala & Mr. Koko & Mr. Sapto & Result \\
\hline $\begin{array}{l}\text { Administration select } \\
\text { textbook }\end{array}$ & $\checkmark$ & $\checkmark$ & & & $50 \%$ \\
\hline $\begin{array}{l}\text { Department head select } \\
\text { textbook }\end{array}$ & $\checkmark$ & $\checkmark$ & & & $50 \%$ \\
\hline $\begin{array}{l}\text { Teachers all together } \\
\text { select textbook }\end{array}$ & $\checkmark$ & $\checkmark$ & $\checkmark$ & $\checkmark$ & $100 \%$ \\
\hline $\begin{array}{l}\text { Teacher select the } \\
\text { textbook }\end{array}$ & $\checkmark$ & $\checkmark$ & $\checkmark$ & $\checkmark$ & $100 \%$ \\
\hline $\begin{array}{l}\text { Learners get involved in } \\
\text { selecting textbook }\end{array}$ & $\checkmark$ & & & $25 \%$ \\
\hline $\begin{array}{l}\text { There is a textbook } \\
\text { criteria }\end{array}$ & $\checkmark$ & $\checkmark$ & $\checkmark$ & $\checkmark$ & $100 \%$ \\
\hline
\end{tabular}

Appendix 2. Result of Teacher's Criteria in Selecting Appropriate Textbook

\begin{tabular}{|c|c|c|c|c|c|c|}
\hline \multirow{2}{*}{ Number } & \multirow{2}{*}{$\begin{array}{l}\text { Criteria of an appropriate } \\
\text { textbook selected by the } \\
\text { teacher }\end{array}$} & \multicolumn{4}{|c|}{ Teacher } & \multirow{2}{*}{ Result } \\
\hline & & 1 & 2 & 3 & 4 & \\
\hline A. & \multicolumn{6}{|l|}{ Program and Course } \\
\hline 1. & $\begin{array}{l}\text { Does the textbook support the } \\
\text { goals and curriculum of the } \\
\text { program? }\end{array}$ & $\checkmark$ & $\checkmark$ & $\checkmark$ & $\checkmark$ & 4 \\
\hline 2. & $\begin{array}{l}\text { Is the textbook part of a series, } \\
\text { and if so, would using the entire } \\
\text { series be appropriate? }\end{array}$ & $\checkmark$ & $\checkmark$ & $\checkmark$ & $\checkmark$ & 4 \\
\hline 3. & $\begin{array}{l}\text { Are a sufficient number of the } \\
\text { course objectives addressed by the } \\
\text { textbook? }\end{array}$ & $\checkmark$ & $\checkmark$ & $\checkmark$ & $\checkmark$ & 4 \\
\hline 4. & $\begin{array}{l}\text { Was this textbook written for } \\
\text { learners of this age group and } \\
\text { background? }\end{array}$ & $\checkmark$ & $\checkmark$ & $\checkmark$ & $\checkmark$ & 4 \\
\hline B. & \multicolumn{6}{|c|}{$\begin{array}{l}\text { Curriculum } 2013 \text { aspect based on content suitability of BNSP } \\
\text { criteria }\end{array}$} \\
\hline 1. & \multicolumn{6}{|c|}{$\begin{array}{l}\text { The suitability of material with core competence }(\mathrm{KI}) \text { and basic } \\
\text { competence }(\mathrm{KD})\end{array}$} \\
\hline a. & $\begin{array}{l}\text { Does the textbook expose the } \\
\text { students to understand and } \\
\text { produce both interpersonal and } \\
\text { transactional conversation? }\end{array}$ & $\checkmark$ & $\checkmark$ & $\checkmark$ & $\checkmark$ & 4 \\
\hline b. & $\begin{array}{c}\text { Does textbook expose the student } \\
\text { with many kind of text that } \\
\text { relevant with student daily life? }\end{array}$ & $\checkmark$ & $\checkmark$ & $\checkmark$ & $\checkmark$ & 4 \\
\hline
\end{tabular}




\begin{tabular}{|c|c|c|c|c|c|c|}
\hline c. & $\begin{array}{c}\text { Does the textbook guide the } \\
\text { student in understanding the } \\
\text { social function, structure text, and } \\
\text { linguistic features? }\end{array}$ & $\checkmark$ & $\checkmark$ & $\checkmark$ & $\checkmark$ & 4 \\
\hline 2. & \multicolumn{6}{|l|}{ The accuracy of the materials } \\
\hline a. & $\begin{array}{l}\text { Does the textbook provide social } \\
\text { linguistic? }\end{array}$ & $\checkmark$ & $\checkmark$ & $\checkmark$ & $\checkmark$ & 4 \\
\hline b. & $\begin{array}{l}\text { Does the textbook provide generic } \\
\text { structure? }\end{array}$ & $\checkmark$ & $\checkmark$ & $\checkmark$ & $\checkmark$ & 4 \\
\hline c. & $\begin{array}{l}\text { Does the textbook provide } \\
\text { linguistic feature? }\end{array}$ & $\checkmark$ & $\checkmark$ & $\checkmark$ & $\checkmark$ & 4 \\
\hline 3. & \multicolumn{6}{|l|}{ Supplementary materials } \\
\hline a. & $\begin{array}{l}\text { Does the textbook material and } \\
\text { exercise up to date? }\end{array}$ & $\checkmark$ & $\checkmark$ & & $\checkmark$ & 4 \\
\hline b. & $\begin{array}{l}\text { Can the textbook develop the life } \\
\text { skill? }\end{array}$ & $\checkmark$ & $\checkmark$ & $\checkmark$ & $\checkmark$ & 4 \\
\hline c. & $\begin{array}{l}\text { Can the textbook develop wawasan } \\
\text { kebhinekaan? }\end{array}$ & $\checkmark$ & $\checkmark$ & & $\checkmark$ & 4 \\
\hline C. & \multicolumn{6}{|l|}{ Practical concern } \\
\hline 1. & Is the textbook available? & $\checkmark$ & $\checkmark$ & $\checkmark$ & $\checkmark$ & 4 \\
\hline 2. & $\begin{array}{l}\text { Can the textbook be obtained in } \\
\text { a timely manner? }\end{array}$ & $\checkmark$ & $\checkmark$ & $\checkmark$ & $\checkmark$ & 4 \\
\hline 3. & Is the textbook cost-effective? & $\checkmark$ & $\checkmark$ & $\checkmark$ & $\checkmark$ & 4 \\
\hline
\end{tabular}

Appendix 3. The teachers' interview guide about their criteria and steps in selecting appropriate English textbook.

1. What do you think about textbooks selection?

2. How important textbook selection in getting an appropriateness?

3. Why should you as a teacher select textbook?

4. What criteria should a good textbook have? Tell me what they are?

5. How should textbooks suit to teachers, students, and administrators?

6. What steps do you employ in selecting textbook? Tell me the process of selecting textbook? 


\section{Appendix 4. Document Analysis Checklist}

\begin{tabular}{|c|c|c|c|c|}
\hline \multirow{2}{*}{ Number } & \multirow{2}{*}{$\begin{array}{l}\text { Criteria an appropriate textbook } \\
\text { selected by the teacher }\end{array}$} & \multicolumn{2}{|c|}{ Scale } & \multirow{2}{*}{ Note } \\
\hline & & Yes & No & \\
\hline A. & \multicolumn{4}{|l|}{ Program and Course } \\
\hline 4 & $\begin{array}{l}\text { Does the textbook support the goals and } \\
\text { curriculum of the program? }\end{array}$ & $\checkmark$ & & \\
\hline 5 & $\begin{array}{l}\text { Is the textbook part of a series, and if so, } \\
\text { would using the entire series be } \\
\text { appropriate? }\end{array}$ & $\checkmark$ & & \\
\hline 6 & $\begin{array}{l}\text { Are a sufficient number of the course } \\
\text { objectives addressed by the textbook? }\end{array}$ & $\checkmark$ & & \\
\hline 7 & $\begin{array}{l}\text { Was this textbook written for learners of } \\
\text { this age group and background? }\end{array}$ & $\checkmark$ & & \\
\hline B. & \multicolumn{4}{|c|}{ Curriculum 2013 aspect based on content suitability of BNSP criteria } \\
\hline 1. & \multicolumn{4}{|c|}{$\begin{array}{l}\text { The suitability of material with core competence (KI) and basic } \\
\text { competence (KD) }\end{array}$} \\
\hline a. & $\begin{array}{c}\text { Does the textbook expose the students to } \\
\text { understand and produce both } \\
\text { interpersonal and transactional } \\
\text { conversation? }\end{array}$ & $\checkmark$ & & \\
\hline b. & $\begin{array}{l}\text { Does textbook expose the student with } \\
\text { many kind of text that relevant with } \\
\text { student daily life? }\end{array}$ & $\checkmark$ & & \\
\hline c. & $\begin{array}{l}\text { Does the textbook guide student in } \\
\text { understanding the social fuction, } \\
\text { structure text, and linguistic features? }\end{array}$ & $\checkmark$ & & \\
\hline 2. & \multicolumn{4}{|l|}{ The accuracy of the material } \\
\hline a. & $\begin{array}{l}\text { Does the textbook provided social } \\
\text { linguistic? }\end{array}$ & $\checkmark$ & & \\
\hline b. & $\begin{array}{l}\text { Does the textbook provided generic } \\
\text { structure? }\end{array}$ & $\checkmark$ & & \\
\hline c. & $\begin{array}{l}\text { Does the textbook provided linguistic } \\
\text { feature? }\end{array}$ & $\checkmark$ & & \\
\hline 3. & \multicolumn{4}{|l|}{ Supplementary material } \\
\hline a. & $\begin{array}{l}\text { Does the textbook material and exercise } \\
\text { up to date? }\end{array}$ & $\checkmark$ & & \\
\hline b. & Can the textbook develop the life skill? & $\checkmark$ & & \\
\hline c. & $\begin{array}{l}\text { Can the textbook develop wawasan } \\
\text { kebhinikaan? }\end{array}$ & $\checkmark$ & & \\
\hline C. & \multicolumn{4}{|l|}{ Practical concern } \\
\hline 1. & Is the textbook available? & $\checkmark$ & & \\
\hline 2. & $\begin{array}{l}\text { Can the textbook be obtained in a timely } \\
\text { manner? }\end{array}$ & $\checkmark$ & & \\
\hline
\end{tabular}


Siti Maftukah, Puji Astuti / ELT Forum 10 (1) (2021)

\begin{tabular}{|l|l|l|l|l|}
\hline 3. & Is the textbook cost-effective? & $\checkmark$ & & \\
\hline
\end{tabular}

